\title{
Article \\ Effect of Silicon Nitride and Graphene Nanoplatelets on the Properties of Aluminum Metal Matrix Composites
}

\author{
Rokaya Abdelatty ${ }^{D}$, Adnan Khan, Moinuddin Yusuf, Abdullah Alashraf and Rana Abdul Shakoor *iD \\ Center for Advanced Materials (CAM), Qatar University, 2713 Doha, Qatar; Rokaya.abdelatty@qu.edu.qa (R.A.); \\ adnan.khan@qu.edu.qa (A.K.); moinuddin@qu.edu.qa (M.Y.); aa.ashraf@qu.edu.qa (A.A.) \\ * Correspondence: shakoor@qu.edu.qa; Tel.: +974-4403-6867
}

Citation: Abdelatty, R.; Khan, A.; Yusuf, M.; Alashraf, A.; Shakoor, R.A. Effect of Silicon Nitride and Graphene Nanoplatelets on the Properties of Aluminum Metal Matrix Composites. Materials 2021, 14, 1898. https://doi.org/10.3390/ma14081898

Academic Editors: Christian Motz and Jordi Sort

Received: 24 February 2021

Accepted: 6 April 2021

Published: 10 April 2021

Publisher's Note: MDPI stays neutral with regard to jurisdictional claims in published maps and institutional affiliations.

Copyright: (c) 2021 by the authors. Licensee MDPI, Basel, Switzerland. This article is an open access article distributed under the terms and conditions of the Creative Commons Attribution (CC BY) license (https:// creativecommons.org/licenses/by/ $4.0 /)$.

\begin{abstract}
This research work aims at investigating the influence of a fixed content of silicon nitride $\left(\mathrm{Si}_{3} \mathrm{~N}_{4}\right)$ and varied contents of graphene nanoplatelets (GNPs) on the physical (density, structural, morphological) and mechanical properties (microhardness, nanoindentation) of $\mathrm{Al}-\mathrm{Si}_{3} \mathrm{~N}_{4}$-GNPs composites. The composites were fabricated by a microwave-assisted powder metallurgy route. The $\mathrm{Si}_{3} \mathrm{~N}_{4}$ concentration was fixed at ( $5 \mathrm{wt}$. $\%$ ) in $\mathrm{Al}-\mathrm{Si}_{3} \mathrm{~N}_{4}$-GNPs composites while the GNPs concentration was varied between $(0 \mathrm{wt} . \%)$ to $(1.5 \mathrm{wt} . \%)$ with an increment of $(0.5 \mathrm{wt} . \%)$. The structural analysis indicates the formation of phase pure materials with high crystallinity. The microstructural analysis confirmed the presence of the $\mathrm{Si}_{3} \mathrm{~N}_{4}$ and GNPs showing enhanced agglomeration with the increasing amount of GNPs. Moreover, the surface roughness of the synthesized composites increases with an increasing amount of GNPs reaching its maximum value (RMS $=65.32 \mathrm{~nm}$ ) at $1.5 \mathrm{wt}$. $\%$ of GNPs. The Al-Si ${ }_{3} \mathrm{~N}_{4}$-GNPs composites exhibit improved microhardness and promising load-indentation behavior during nanoindentation when compared to pure aluminum (Al). Moreover, $\mathrm{Al}-\mathrm{Si}_{3} \mathrm{~N}_{4}-\mathrm{GNPs}$ composites demonstrate higher values of compressive yield strength (CYS) and ultimate compressive strength (UCS) when compared to pure Al despite showing a declining trend with an increasing amount of GNPs in the matrix. Finally, a shear mode of fracture is prevalent in $\mathrm{Al}-\mathrm{Si}_{3} \mathrm{~N}_{4}-\mathrm{GNPs}$ composites under compression loading.
\end{abstract}

Keywords: aluminum; composites; microwave sintering; microstructure; nanoindentation; hardness; strength

\section{Introduction}

Metal matrix composites (MMCs) are promising sophisticated materials that incorporate a metallic matrix such as aluminum (Al) and reinforcement particles which commonly are affiliated to families of borides, carbides, nitrides, and oxides [1,2]. In the family of MMCs, the aluminum metal matrix composites (AMMCs) have attracted much attention due to their distinctive properties such as low density, high strength, good wear resistance, and excellent thermal stability [3-5]. These features lead AMMCs to become a prospective contender for comprehensive utilization in the automobile and aviation industries [6]. At the same time, research have demonstrated that the incorporation of nano-sized reinforcements in AMMCs has exhibited superior behavior in enhancing their structural, thermal, and mechanical properties when compared with micron-sized reinforcements $[7,8]$.

Nowadays, the production of Al-composites with nano-sized reinforcements undergoes multiple types of experimental research owing to the large specific surface area represented by the nanoparticles, which give rise to a strong contact interfacial area between the base material and its reinforcement [9-11]. This characteristic improves the mechanical behavior of the composites resulting in a superior nanotribological performance [12]. Different types of reinforcements such as metallic, amorphous, and ceramic particles, have been utilized in AMMCs for enhancing their performances. The selection of the reinforcements depends on the eventual desired and targeted properties of the AMMCs [13]. 
Recent studies have indicated that the properties are remarkably influenced by the nature of reinforcement, its weight fraction, and distribution within the metal matrix [6,14-16]. To optimize the properties of the AMMCs, the reinforcement material utilized is required to be uniformly distributed within the matrix. Different mixing techniques such as solutionassisted mixing, molten or liquid metal processes and ball milling has been applied to the reinforcements to obtain their uniform distribution within the metal matrix. Among these techniques, the ball milling process has attracted wide attention for its considerable impact on the microstructure of the product. Once utilized at the optimum operating conditions that conform with the feed material, it produces homogeneously distributed reinforcements within the metal matrix by enhancing the affinity between the reinforcement and the matrix [17].

Moreover, the ultimate properties of the AMMCs depend on the fabrication method. Several fabricating techniques have been reported for the manufacturing of AMMCs such as casting, thermomechanical processing, and the powder metallurgy (PM) route. The PM method is the most employed fabricating technique for the production of AMMCs owing to its ability in maintaining a high level of homogeneity of distributed reinforcements [18]. The PM method usually consists of four main stages. The first stage is the powder preparation stage where the powders of the aluminum matrix and the reinforcements are prepared. The second stage is the ball milling stage where the powders of aluminum and reinforcements are mixed. Powder products are then taken to the third stage of cold pressing to create cylindrical pellets where it will be taken for the final stage to microwave sintering to form the final homogenous product [19].

In the present study, silicon nitride $\left(\mathrm{Si}_{3} \mathrm{~N}_{4}\right)$ was selected as the first reinforcement based on its significant properties such as high hardness, compressive strength, wear-resistance, and high thermal stability [20,21]. Additionally, graphene nanoplatelets (GNPs) were considered as the second reinforcement for the manufacturing of hybrid aluminum metal matrix composites (HAMMCs) due to their extraordinary mechanical and tribological, electrical, and thermal properties [6,22,23]. The amount of $\mathrm{Si}_{3} \mathrm{~N}_{4}$ was kept constant at $5 \mathrm{wt} . \%$, whereas the amount of GNPs was varied from 0.5 to $1.5 \mathrm{wt} . \%$ to study their effect on the structural, and mechanical properties of the synthesized HAMMCs. It is observed that the amount of GNPs has a substantial impact on the structural and mechanical properties of the HAMMCs. The novelty of the present work resides in the fact that the composites were fabricated through a microwave sintering approach, which is quite efficient and provides cost-effectiveness, better process control, meticulous microstructure, improved properties and scaling up in the process. The development of $\mathrm{Al}-\mathrm{Si}_{3} \mathrm{~N}_{4}$-GNPs through a microwave sintering approach has not been reported earlier.

\section{Materials and Methods}

Pure Al powder (99.5\% purity, Alfa Aesar, Tewksbury, MA, USA) with a particle size of 7-15 $\mu \mathrm{m}$ was used as the matrix material. Crystalline $\mathrm{Si}_{3} \mathrm{~N}_{4}$ powder $(98.5+\%$ purity, Alfa Aesar, Tewksbury, MA, USA) with a particle size of $15-30 \mathrm{~nm}$ and GNPs powder $(97 \%$ purity, Cheap Tubes, Cambridge port, VT, USA) with an average particle size of 8-15 nm were used as reinforcement materials for the synthesis of $\mathrm{Al}-\mathrm{Si}_{3} \mathrm{~N}_{4}$-GNPs composites. The $\mathrm{Si}_{3} \mathrm{~N}_{4}$ contents were fixed while the amount of GNPs was varied in the Al matrix to develop $\mathrm{Al}-\mathrm{Si}_{3} \mathrm{~N}_{4}$-GNPs composites. The composition of fabricated Al-Si $\mathrm{N}_{4}$-GNPs composites is presented in Table 1.

Table 1. Composition of $\mathrm{Al}_{-} \mathrm{Si}_{3} \mathrm{~N}_{4}$-GNPs composites.

\begin{tabular}{ccc}
\hline Sample No. & Sample Title & Weight Fraction (wt.\%) \\
\hline 1 & $\mathrm{~S} 1$ & Pure $\mathrm{Al}$ \\
2 & $\mathrm{~S} 2$ & $\mathrm{Al}-5 \mathrm{wt} . \% \mathrm{Si}_{3} \mathrm{~N}_{4}$ \\
3 & $\mathrm{~S} 3$ & $\mathrm{Al}-5 \mathrm{wt} . \% \mathrm{Si}_{3} \mathrm{~N}_{4}-0.5 \mathrm{wt} \% \mathrm{GNPs}$ \\
4 & $\mathrm{~S} 4$ & $\mathrm{Al}-5 \mathrm{wt} \% \mathrm{Si}_{3} \mathrm{~N}_{4}-1.0 \mathrm{wt} \% \mathrm{GNPs}$ \\
5 & $\mathrm{~S} 5$ & $\mathrm{Al}-5 \mathrm{wt} . \% \mathrm{Si}_{3} \mathrm{~N}_{4}-1.5 \mathrm{wt} \% \mathrm{GNPs}$ \\
\hline
\end{tabular}


The powder metallurgy method was employed for the fabrication of the $\mathrm{Al}^{-} \mathrm{Si}_{3} \mathrm{~N}_{4}$ GNPs composites utilizing ball milling and microwave sintering techniques. Powders of the matrix and reinforcements were weighed using an analytical balance (Sartorius, ENTRIS64-1S, Lower Saxony, Germany) and then were uniformly mixed using a planetary ball mill (PM200, RETSCH 20.640.0001, Haan, Germany). Powders were blended at room temperature for a duration of $2 \mathrm{~h}$ at a milling speed set at 200 RPM to obtain a homogenous distribution of the nanoparticle reinforcements in the matrix. The blended powder mixtures ( $1.0 \mathrm{~g})$ were cold-compressed under an applied pressure of $50 \mathrm{MPa}$ and a residence time of $1 \mathrm{~min}$ to form cylindrical pellets. The green pellets were sintered using a bidirectional microwave-assisted rapid sintering technique supplied by (VB ceramic furnace, $\mathrm{VBCC} / \mathrm{MF} / 1600^{\circ} \mathrm{C} / 14 / 15$, Chennai, India). The operating conditions of the microwave sintering were programmed at a temperature of $550{ }^{\circ} \mathrm{C}$ utilizing a rapid heating rate of $10^{\circ} \mathrm{C} / \mathrm{min}$ and a dwell time of $30 \mathrm{~min}$. After microwave sintering, the sintered pellets were cooled down to room temperature $\left(25^{\circ} \mathrm{C}\right)$ and then characterized using various techniques. An illustration of the experimental procedure for the fabrication of $\mathrm{Al}_{-} \mathrm{Si}_{3} \mathrm{~N}_{4}$ GNPs composites is presented in Figure 1.
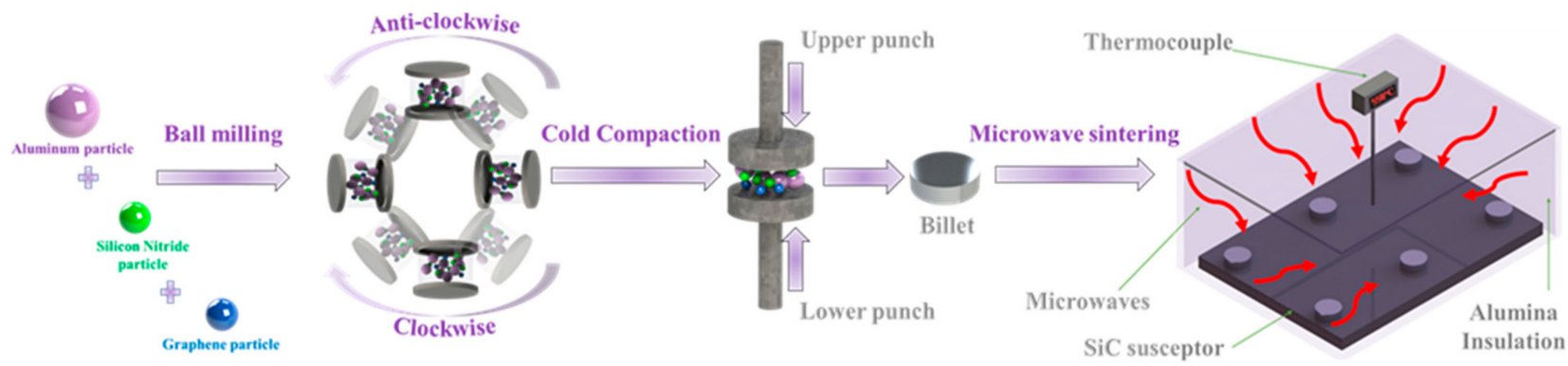

Figure 1. Schematic representation for the development of $\mathrm{Al}-\mathrm{Si}_{3} \mathrm{~N}_{4}-\mathrm{GNPs}$ composites.

Phase analysis of microwave sintered hybrid composites was carried out using an X-ray diffractometer (XRD) (PANalytical X'pert pro, PANalytical B.V., Almelo, The Netherlands). The XRD spectra were documented in the range of $2 \theta=20-80^{\circ}$ at $45 \mathrm{kV}$ and $40 \mathrm{~mA}$ employing $\mathrm{Cu}$ anode radiation, with a scanning rate of $1.5^{\circ} / \mathrm{min}$ and a step size of $0.02^{\circ}$. Microstructural analysis was performed on the polished sintered pellets using a field emission scanning electron microscope (FE-SEM) (SEM-FEI Nova NanoSEM 450 FE-SEM, Hillsboro, OR, USA). Elemental mapping analysis was conducted with Energy-dispersion $X$-ray spectroscopy (EDS) (Bruker SDD-EDS, Coventry, UK) to evaluate the composition and phase purity of the fabricated HAMMCs.

The density and porosity of the $\mathrm{Al}-\mathrm{Si}_{3} \mathrm{~N}_{4}$-GNPs composites were calculated based on Archimedes' principle. Density kit analytical balance (Sartorius YDK03, Lower Saxony, Germany) with a precision of $\pm 0.0001 \mathrm{~g}$ was used for the calculation. The surface topography of the fabricated $\mathrm{Al}-\mathrm{Si}_{3} \mathrm{~N}_{4}$-GNPs composites was examined using an atomic force microscope (AFM) (MFP-3D AFM, Asylum Research, Oxford, UK). Nano-hardness and Young's modulus were analyzed at room temperature conditions using a nanoindenter (MFP-3D Nano Indenter, Asylum Research, Oxford, UK). Forces were applied to the samples at a maximum load of $1 \mathrm{mN}$, and dwell time of $5 \mathrm{~s}$ at the peak load. The indentation displacement was observed and documented within the nm range.

The Microhardness of the developed $\mathrm{Al}-\mathrm{Si}_{3} \mathrm{~N}_{4}$-GNPs composites was examined using a Vickers tester (FM-ARS9000, MKV-h21, Tokyo, Japan). Five successive iterations were undertaken on each specimen to achieve high accuracy in results with an applied load of $5 \mathrm{gf}$ and a dwell time of $10 \mathrm{~s}$. Compression analysis of the composites was accomplished using a universal testing machine (Lloyd, USA-LR50Kplus, Sussex, UK) at standard conditions of temperature and pressure under an engineering strain rate of $0.6 \mathrm{~mm} / \mathrm{min}$. The documented data was an average value of four successive test results. The fractographic analysis was conducted on the fractured surfaces of $\mathrm{Al}-\mathrm{Si}_{3} \mathrm{~N}_{4}$-GNPs composites using a 
field emission scanning electron microscope (SEM-FEI Nova NanoSEM 450 FE-SEM, OR, USA) to understand the mode of fracture during the compression testing.

\section{Results and Discussion}

\subsection{Characterization of Raw Materials}

Figure 2 represents the FE-SEM images of (a) pure $\mathrm{Al}$, (b) $\mathrm{Si}_{3} \mathrm{~N}_{4}$ and (c) GNPs powders utilized in the fabrication of $\mathrm{Al}_{-} \mathrm{Si}_{3} \mathrm{~N}_{4}$-GNPs composites. The morphology of the pure $\mathrm{Al}$ and $\mathrm{Si}_{3} \mathrm{~N}_{4}$ can be clearly seen in Figure 2a,b, respectively, while Figure $2 \mathrm{c}$ depicts the platelike structure of GNPs. The provided micrographs confirm the size of the reinforcements in the nanometric. The scale bar on FE-SEM images presented in Figure $2 b, c$ clearly depicts the nanometric size of the reinforcements confirming the development of composites.

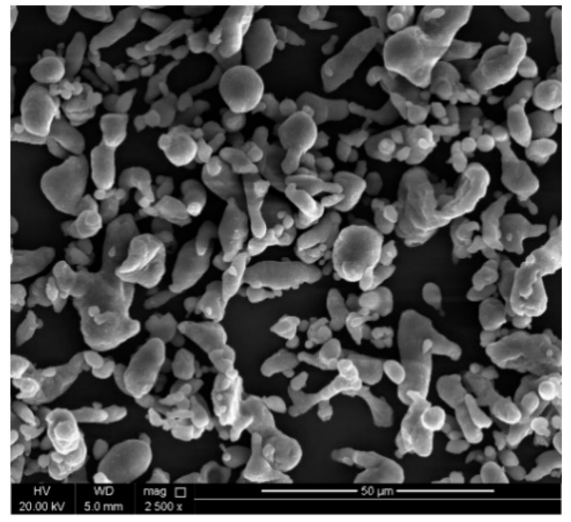

(a)

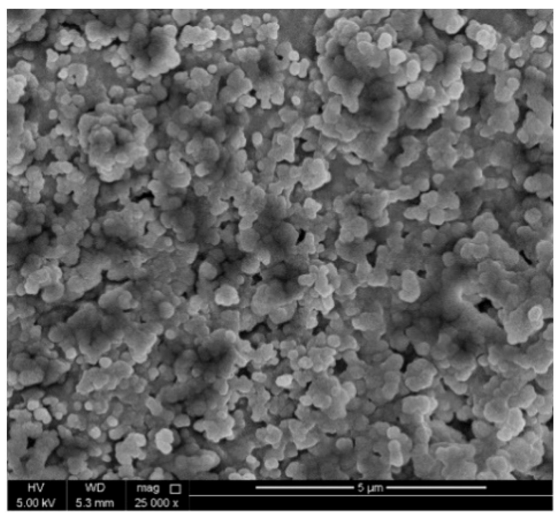

(b)

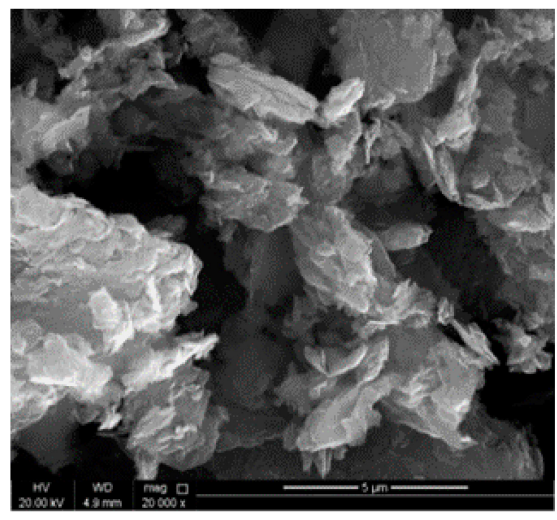

(c)

Figure 2. FE-SEM images of as received powders of (a) Pure Al, (b) $\mathrm{Si}_{3} \mathrm{~N}_{4}$ and (c) GNPs.

\subsection{XRD Analysis of Al-Si $\mathrm{N}_{4}$-GNPs Composites}

Figure 3a illustrates the XRD spectra of the microwave-sintered pure $\mathrm{Al}$ and the manufactured $\mathrm{Al}_{-} \mathrm{Si}_{3} \mathrm{~N}_{4}$-GNPs composites consisting of disparate weight fractions of GNPs. The results verify the presence of $\mathrm{Si}_{3} \mathrm{~N}_{4}$ and GNPs in the $\mathrm{Al}$ matrix. It is noticed that the intensity of the $\mathrm{Al}$ peaks is high due to its high concentration in the $\mathrm{Al}^{-\mathrm{Si}_{3} \mathrm{~N}_{4} \text {-GNPs }}$ composites indicating its crystalline character. However, the low intensity of peaks of the reinforcements $\left(\mathrm{Si}_{3} \mathrm{~N}_{4}\right.$ and GNPs) are detected due to their low amount in the Al$\mathrm{Si}_{3} \mathrm{~N}_{4}$-GNP composites, which is consistent with the previous studies [24]. Moreover, $X R D$ results did not show any traces of undesired phases or impurities such as aluminum carbide $\left(\mathrm{Al}_{4} \mathrm{C}_{3}\right)$ for $\mathrm{S} 3, \mathrm{~S} 4$ and $\mathrm{S} 5$ due to the low contents of GNPs incorporated in the $\mathrm{Al}$ matrix $[25,26]$. It can also be observed that the intensity of the GNPs reinforcement peaks rises with the increase in the concentration of the reinforcement. The enlarged section in Figure $3 \mathrm{a}$ from the diffraction angle $20-35^{\circ}$ demonstrates the augmentation of the intensity of GNPs with the increase of the reinforcement content in the Al matrix. XRD patterns of S5 were magnified and illustrated in Figure $3 \mathrm{~b}$ to clearly signify the presence of $\mathrm{Al}$, crystalline $\mathrm{Si}_{3} \mathrm{~N}_{4}$, and GNPs in the matrix. Additionally, it confirms the absence of other impurities in the Al-Si $\mathrm{N}_{4}$-GNPs composites showing close adherence with the previous studies [27,28]. The XRD results indicate that phase pure $\mathrm{Al}_{-} \mathrm{Si}_{3} \mathrm{~N}_{4}$-GNPs composites containing various concentrations of GNPs is successfully developed through the microwave-assisted powder metallurgy route. 

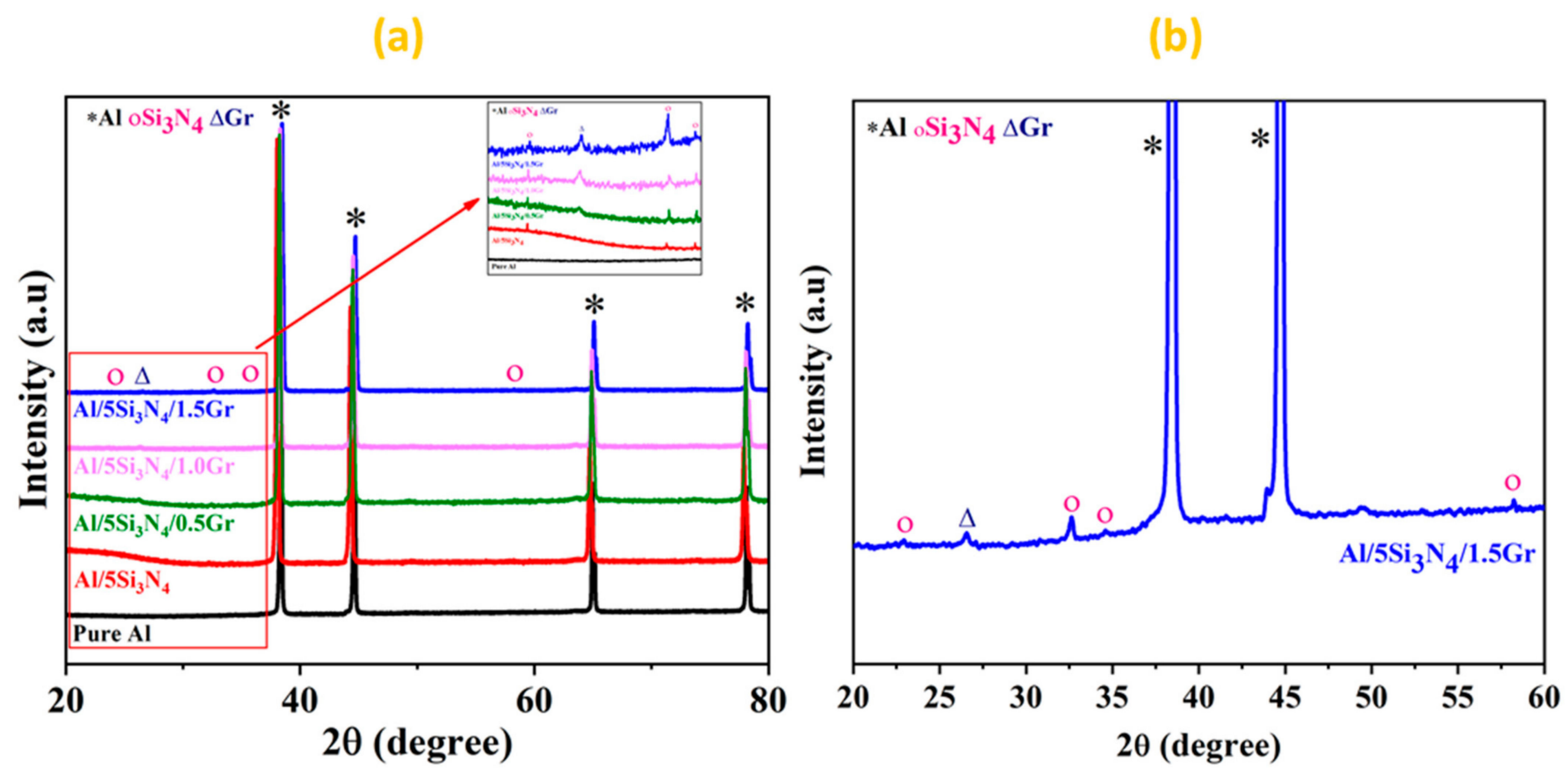

Figure 3. X-ray diffraction patterns of (a) $\mathrm{Al}_{-} \mathrm{Si}_{3} \mathrm{~N}_{4}$-GNPs composites (inset graph shows the enlarged section that covers the $2 \theta$ range $20-35^{\circ}$ ) and (b) Magnified pattern of $A 1-5 \mathrm{Si}_{3} \mathrm{~N}_{4}-1.5 \mathrm{GNPs}$ composites.

\subsection{Microstructural Analysis of Al-Si ${ }_{3} \mathrm{~N}_{4}$-GNPs Composites}

Figure 4 represents FE-SEM images of the fabricated $\mathrm{Al}_{-} \mathrm{Si}_{3} \mathrm{~N}_{4}$-GNPs composites containing various weight fractions of GNPs. The FE-SEM images reveal the distribution of Si3N4 (white areas indicated with blue arrows) and GNPs (light grey areas indicated with green arrows) are evenly distributed within the $\mathrm{Al}$ matrix (dark grey area). Homogenous distribution of $\mathrm{Si}_{3} \mathrm{~N}_{4}$ nanoparticles in the Al matrix was observed in the sample S2 as shown in Figure $4 \mathrm{~b}$. On the other hand, some agglomeration of reinforcement is also detected in some areas of samples S3, S4, and S5. The agglomeration tendency increased with the increase of GNPs in $\mathrm{Al}-\mathrm{Si}_{3} \mathrm{~N}_{4}$-GNPs composites as shown in Figure 4c-e. The agglomeration of particles has also been previously reported and can be attributed to the electrostatic attractive forces [24,29].

Figure 5 represents the EDX analysis of the fabricated $\mathrm{Al}-\mathrm{Si}_{3} \mathrm{~N}_{4}$-GNPs composites (S3, S4, and S5) as depicted in Figure 5a-c with their corresponding elemental mapping images (Figure $5 \mathrm{~d}-\mathrm{f}$ ) showing elemental distribution. The images indicate the presence of $\mathrm{Al}, \mathrm{Si}, \mathrm{N}$, and $\mathrm{C}$ as the main elements in the composites. The composition of S3, S4, and S5 is also presented in Table 2. It is worth mentioning that the illustrated elemental mapping images have proven the uniform and even distribution of the reinforcements in the fabricated $\mathrm{Al}-\mathrm{Si}_{3} \mathrm{~N}_{4}$-GNPs composites with a small agglomeration.

Table 2. Elemental distribution of $\mathrm{Al}-5 \mathrm{Si}_{3} \mathrm{~N}_{4}-0.5 \mathrm{GNPs}, \mathrm{Al}-5 \mathrm{Si}_{3} \mathrm{~N}_{4}-1 \mathrm{GNPs}$ and $\mathrm{Al}-5 \mathrm{Si}_{3} \mathrm{~N}_{4}-1.5 \mathrm{GNP}$ composites in correspondence to EDX spectrum Figure 5a-c.

\begin{tabular}{cccc}
\hline \multirow{2}{*}{ Element } & \multicolumn{3}{c}{ Weight Percent (wt.\%) } \\
\cline { 2 - 4 } & S3 & S4 & S5 \\
\hline $\mathrm{Al}$ & 74.42 & 68.35 & 65.25 \\
$\mathrm{Si}$ & 1.65 & 1.59 & 0.22 \\
$\mathrm{~N}$ & 5.30 & 5.94 & 3.43 \\
$\mathrm{C}$ & 9.74 & 10.99 & 22.31 \\
$\mathrm{O}$ & 8.89 & 13.13 & 8.79 \\
Total & 100 & 100 & 100 \\
\hline
\end{tabular}



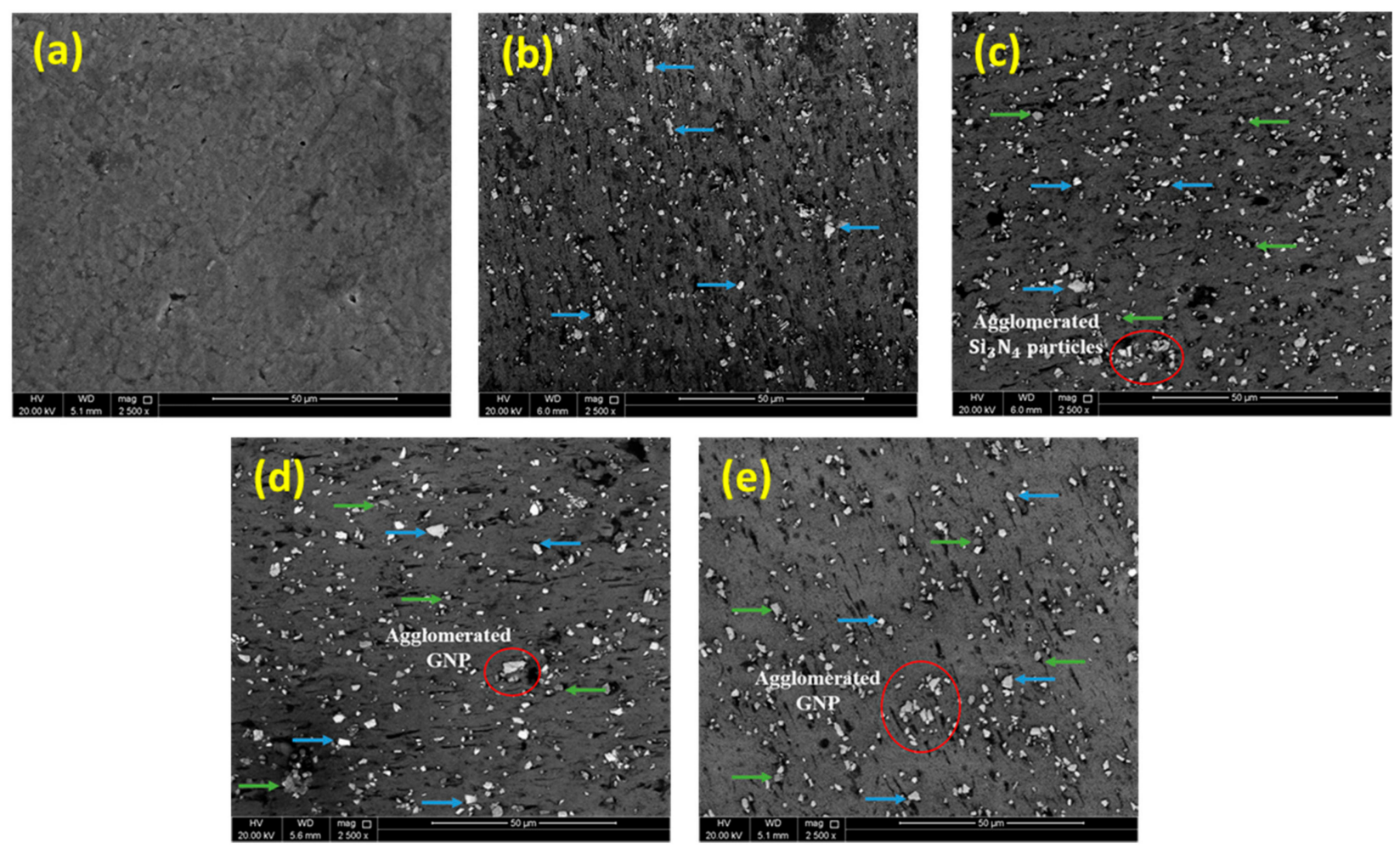

Figure 4. FE-SEM images of (a) Pure Al, (b) Al-5Si ${ }_{3} N_{4}$, (c) Al- $5 S_{3} \mathrm{~N}_{4}-0.5 G N P s$, (d) Al-5Si $\mathrm{N}_{4}-1 G N P s$ and (e) Al-5Si ${ }_{3} \mathrm{~N}_{4}-$ 1.5GNPs composites.

\subsection{Density and Porosity of $\mathrm{Al}_{-} \mathrm{Si}_{3} \mathrm{~N}_{4}$-GNPs Composites}

Table 3 demonstrates the experimental outcomes for the measured density and porosity of the developed $\mathrm{Al}_{-} \mathrm{Si}_{3} \mathrm{~N}_{4}$-GNP composites by varying GNP contents in the $\mathrm{Al}$ matrix. It can be noticed that the measured density of the $\mathrm{Al}$ matrix has increased with the addition of the crystalline $\mathrm{Si}_{3} \mathrm{~N}_{4}$ nanoparticles in the matrix (S2) owing to its high theoretical density $\mathrm{Si}_{3} \mathrm{~N}_{4}\left(3.17 \mathrm{~g} / \mathrm{cm}^{3}\right)$ in comparison to that of the Al base metal $\left(2.7 \mathrm{~g} / \mathrm{cm}^{3}\right)$ [30]. The decline in the behavior of the density is observed with the inclusion of GNPs to the Al matrix which could be justified due to the low theoretical density of GNPs $\left(2.267 \mathrm{~g} / \mathrm{cm}^{3}\right)$ [9]. This is so because the contents of $\mathrm{Si}_{3} \mathrm{~N}_{4}$ are fixed in the composites and the incorporation of GNPs in the matrix is thus accomplished at the replacement of Al contents. Furthermore, the density of the composites is found to decrease with the increasing amount of GNPs due to an incremental decrease in the density of the Al matrix due to its replaced amount by GNPs. A similar trend in the density results was noticed in a previous study conducted on Al-Graphene composites $[10,17]$. For a deeper insight into the density behavior of the composites, relative density $\left(\rho_{r}\right)$ of the developed composites was determined using the actual or measured density $\left(\rho_{c}\right)$ and the theoretical density values $\left(\rho_{t}\right)$ as indicated in the below Equation [31].

$$
\rho_{r}(\%)=\left(\rho_{c} / \rho_{t}\right) \times 100
$$



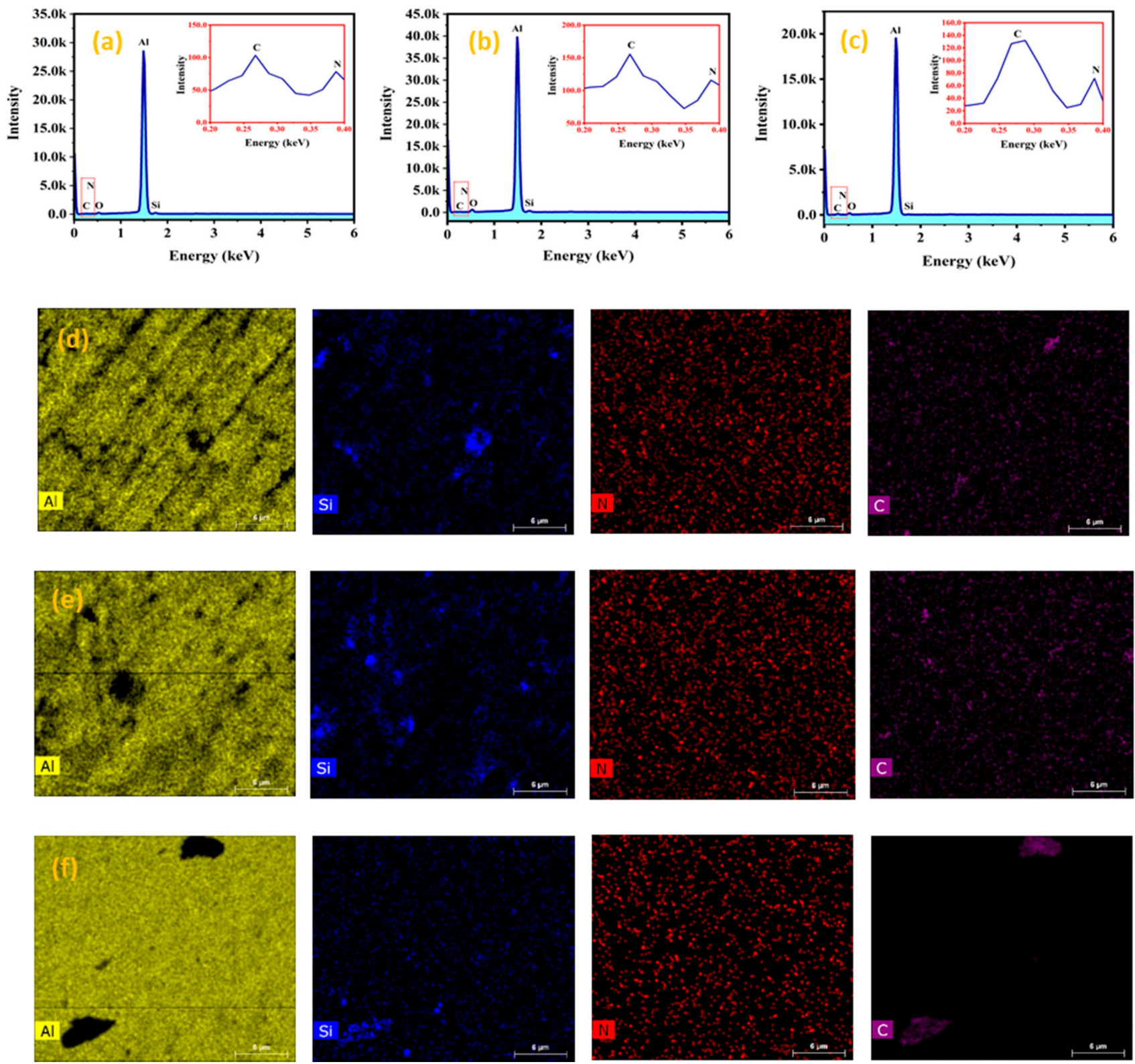

Figure 5. (a-c) Energy dispersive $\mathrm{X}$-ray spectroscopy spectrum analysis and (d-f) elemental mapping images of $\mathrm{Al}_{-}-5 \mathrm{Si}_{3} \mathrm{~N}_{4}$ 0.5GNPs, Al-5Si $\mathrm{N}_{4}-1 \mathrm{GNPs}$ and $\mathrm{Al}-5 \mathrm{Si}_{3} \mathrm{~N}_{4}-1.5 \mathrm{GNPs}$ composites (scale-6 $\mu \mathrm{m}$ ).

Table 3. Density and porosity measurements of $\mathrm{Al}-\mathrm{Si}_{3} \mathrm{~N}_{4}-\mathrm{GNPs}$ composites.

\begin{tabular}{|c|c|c|c|c|}
\hline $\begin{array}{l}\text { Composite } \\
\text { Samples }\end{array}$ & $\begin{array}{c}\text { Theoretical } \\
\text { Density }\left(\mathrm{g} / \mathrm{cm}^{3}\right)\end{array}$ & $\begin{array}{c}\text { Experimental } \\
\text { Density }\left(\mathrm{g} / \mathrm{cm}^{3}\right)\end{array}$ & $\begin{array}{c}\text { Relative } \\
\text { Density (\%) }\end{array}$ & Porosity (\%) \\
\hline S1 & 2.700 & $2.568 \pm 0.002$ & 95.10 & $4.90 \pm 0.058$ \\
\hline S2 & 2.720 & $2.610 \pm 0.003$ & 95.95 & $4.05 \pm 0.100$ \\
\hline S3 & 2.718 & $2.576 \pm 0.002$ & 94.81 & $5.20 \pm 0.084$ \\
\hline $\mathrm{S} 4$ & 2.715 & $2.560 \pm 0.006$ & 94.30 & $5.70 \pm 0.239$ \\
\hline S5 & 2.712 & $2.556 \pm 0.006$ & 94.22 & $5.78 \pm 0.231$ \\
\hline
\end{tabular}

Table 3 shows a higher relative density of $\mathrm{Al}_{-} \mathrm{Si}_{3} \mathrm{~N}_{4}$ composite (S2) ( $\left.25.95 \%\right)$ than that of Al matrix (S1) ( 95.91\%), which indicates the decent interfacial interaction at the $\mathrm{Al}-\mathrm{Si}_{3} \mathrm{~N}_{4}$ interface. However, a decrease in the relative density has been noticed with the increase of the GNP content in the Al matrix, where it reached its terminal value at 
( 94.22\%). This decrease in the densities with the addition of GNPs is in line with the already published reports [6].

Concurrently, the percentage of porosity was calculated and found to be decreasing after the addition of $\mathrm{Si}_{3} \mathrm{~N}_{4}$ nanoparticles to the $\mathrm{Al}$ matrix (S2), as shown in Table 3. The good dispersion and uniform distribution of $\mathrm{Si}_{3} \mathrm{~N}_{4}$ within the $\mathrm{Al}$ matrix has resulted in a lack of agglomerations of the reinforcement and thus reduced the porosity of the $\mathrm{Al}-\mathrm{Si}_{3} \mathrm{~N}_{4}$ composite [32]. However, with the successive addition of GNPs to the composites, the porosity level is noticed to increase due to agglomeration of GNPs in the Al-Si $3 \mathrm{~N}_{4}-\mathrm{GNPs}$ composites (S3, S4, and S5) as presented in Table 3.These findings are consistent with previous studies [33].

\subsection{Surface Topography Al-Si $\mathrm{N}_{4}$-GNPs Composites}

The surface topography of the fabricated composites was examined using atomic force microscopy. Figure 6 represents the AFM images of synthesized $\mathrm{Al}_{-} \mathrm{Si}_{3} \mathrm{~N}_{4}$-GNP composites. The surface roughness was evaluated using the root-mean-square (RMS) roughness parameter which described the smoothness of the surface. The measured RMS value of the pure $\mathrm{Al}$ matrix is $(16.37 \mathrm{~nm})$. The surface roughness of the composites is noticed to increase with the addition of $\mathrm{Si}_{3} \mathrm{~N}_{4}$ used as a reinforcement $(34.7 \mathrm{~nm})$. There is a further increase in the RMS value by the addition of GNPs $(49.11 \mathrm{~nm})$. The RMS value rises with the rising quantity of GNPs in the Al-Si ${ }_{3} \mathrm{~N}_{4}-\mathrm{GNPs}$ composites and it reaches its maximum value at $(65.32 \mathrm{~nm})$ at the highest compositions ( $\left.\mathrm{Al}_{-}-5 \mathrm{Si}_{3} \mathrm{~N}_{4}-1.5 \mathrm{GNPs}\right)$. This behavior of incremental increase in the surface roughness of $\mathrm{Al}_{-} \mathrm{Si}_{3} \mathrm{~N}_{4}$-GNPs composites could be ascribed to the amalgamation of hard ceramic nanoparticles into the Al matrix and the formation of agglomerated $\mathrm{Si}_{3} \mathrm{~N}_{4}$ and GNPs within the $\mathrm{Al}$ matrix as observed in FE-SEM images Figure $4 c-$ e. A similar trend of roughness increment was noticed in the previous studies [34,35].

\subsection{Nanoindentation Analysis and Microhardness of Al-Si ${ }_{3} N_{4}-G N P$ S Composites}

The load-indentation depth curves of the pure $\mathrm{Al}$ and developed $\mathrm{Al}-\mathrm{Si}_{3} \mathrm{~N}_{4}$-GNP composites containing different contents of GNPs are presented in Figure 7a. It can be noticed that the indentation depth decreases with the increasing content of reinforcements, suggesting an improvement in the hardness of the Al-Si $\mathrm{N}_{4}-\mathrm{GNPs}$ composites in comparison to the pure Al. For a clear comparison, the hardness and Young's modulus of pure aluminum (S1) and the various developed $\mathrm{Al}-\mathrm{Si}_{3} \mathrm{~N}_{4}-\mathrm{GNP}$ composites are also presented in Figure $7 \mathrm{~b}$. It can be observed that the hardness and Young's modulus of $\mathrm{Al}-\mathrm{Si}_{3} \mathrm{~N}_{4}-\mathrm{GNPs}$ composites increase with increasing concentration of GNPs. Such behavior is attributed to the presence of GNPs having a positive influence in improving the mechanical properties of pure $\mathrm{Al}[6,17]$. Besides, the presence of hard crystalline $\mathrm{Si}_{3} \mathrm{~N}_{4}$ nanoparticles has also contributed to improving the hardness of the pure Al matrix [36]. The highest value of hardness is demonstrated by sample S5 $(0.899 \pm 45.5 \mathrm{GPa})$ contributing an enhancement of $\sim 32.1 \%$ as compared to sample S1 (pure aluminum, $0.68 \pm 52.65 \mathrm{GPa}$ ). Moreover, Young's modulus of the developed composite was found to improve from ( $6.23 \pm 0.45 \mathrm{GPa})$ at S1 in pure aluminum to $(10.55 \pm 1.00 \mathrm{GPa})$ at S5 in the highest GNPs content of the composites, offering $\sim 69.3 \%$ of development as compared to pure $\mathrm{Al}$. 

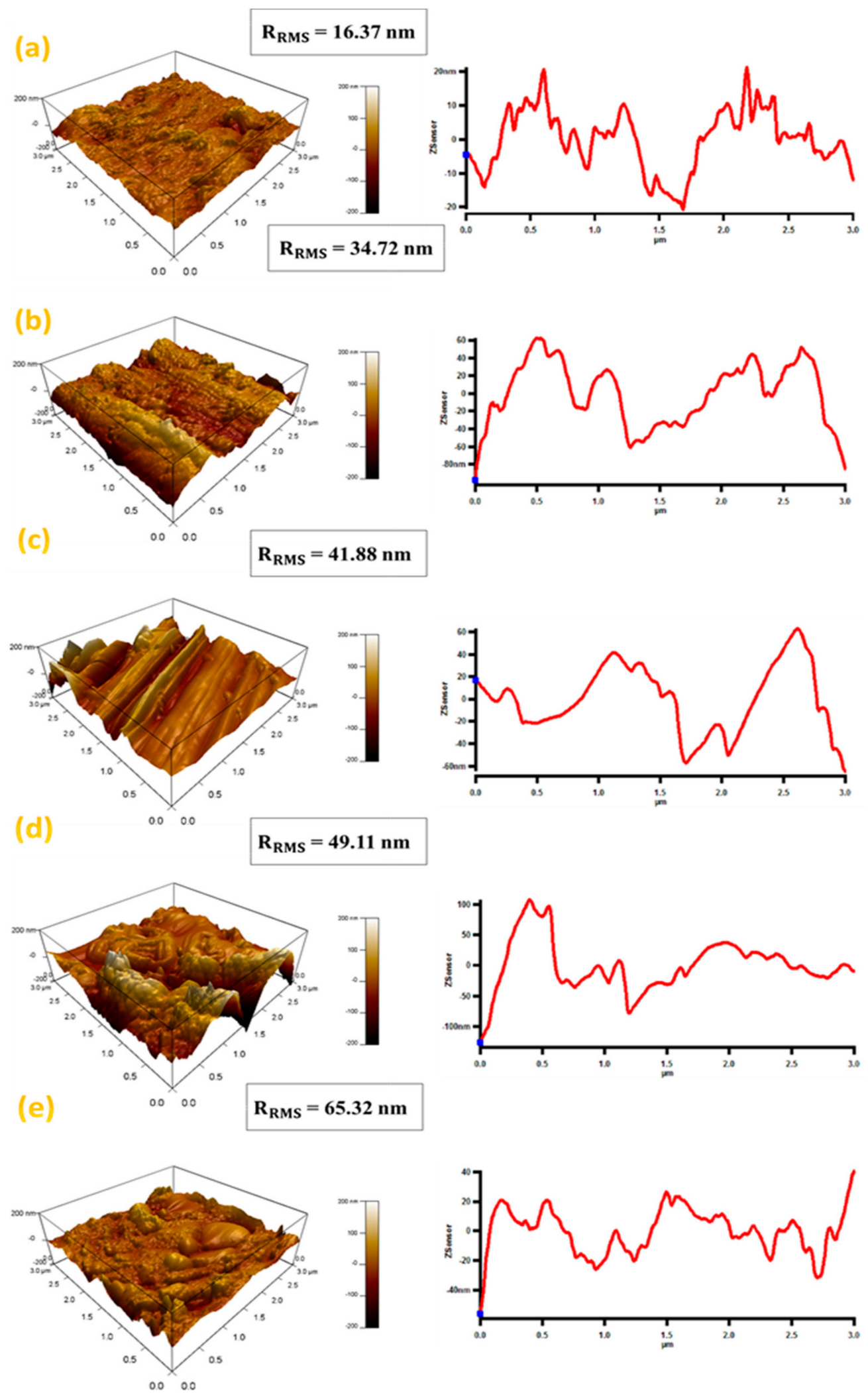

Figure 6. $2 \mathrm{D}$ and $3 \mathrm{D}$ atomic force microscope images of (a) Pure Al, (b) $\mathrm{Al}-5 \mathrm{Si}_{3} \mathrm{~N}_{4}$, (c) $\mathrm{Al}-5 \mathrm{Si}_{3} \mathrm{~N}_{4}-0.5 \mathrm{GNPs},(\mathbf{d}) \mathrm{Al}-5 \mathrm{Si}_{3} \mathrm{~N}_{4}-$ $1 \mathrm{GNPs}$ and (e) $\mathrm{Al}-5 \mathrm{Si}_{3} \mathrm{~N}_{4}-1.5 \mathrm{GNPs}$ composites. 

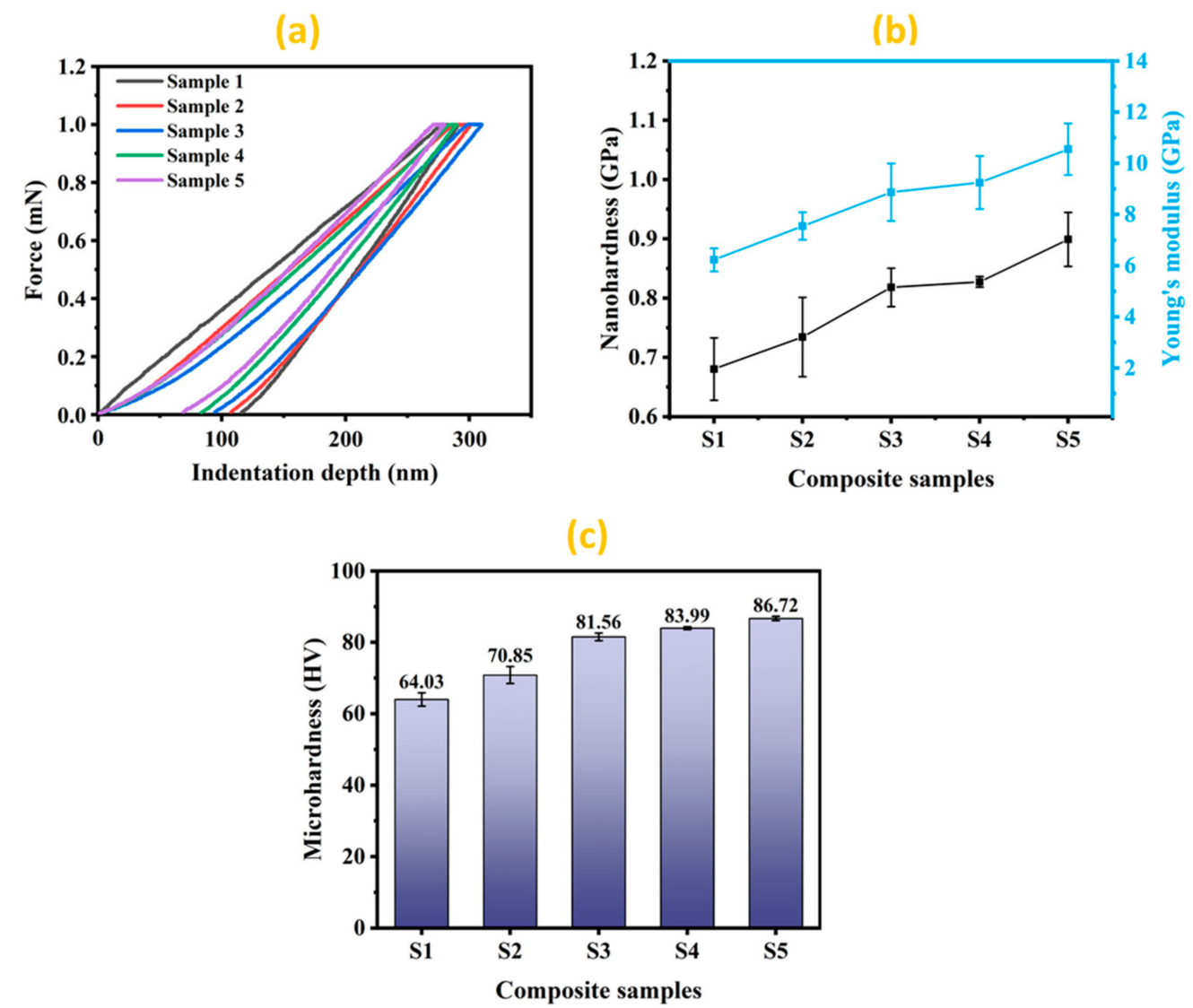

Figure 7. (a) Load-indentation depth curves, (b) Nanohardness and Young's modulus and (c) Microhardness values of $\mathrm{Al}-\mathrm{Si}_{3} \mathrm{~N}_{4}$-GNPs composites.

A comparison of microhardness of pure $\mathrm{Al}$ and developed $\mathrm{Al}-\mathrm{Si}_{3} \mathrm{~N}_{4}$-GNPs composites is also illustrated in Figure 7c. It can be noticed that the microhardness values of the developed $\mathrm{Al}-\mathrm{Si}_{3} \mathrm{~N}_{4}$-GNPs composites have exhibited better performance than that of the pure $\mathrm{Al}$ matrix $(64.03 \pm 1.86 \mathrm{HV})$. As indicated in the graph, the microhardness is gradually increasing in conjunction with the addition of GNPs contents in the Al matrix. The terminal value of microhardness $(86.72 \pm 0.55 \mathrm{HV})$ is obtained in sample S5, which contains maximum contents of GNPs contributing an improvement of $\sim 35.4 \%$. An explanation for the rise of microhardness with the addition of reinforcement from its initial value could be attributed to the dispersion hardening effect as a result of the presence of hard reinforcements [6] and the uniform distribution of $\mathrm{Si}_{3} \mathrm{~N}_{4}$ and GNPs avoiding excessive agglomeration. More importantly, the phenomenon of dispersion hardening has played a critical role in increasing the hardness of the pure $\mathrm{Al}$ matrix [14]. Additionally, the enhancement in hardness with the increasing amount of reinforcement can also be explained by the rule of the mixture as stated below [37].

$$
H_{c}=H_{m} F_{m}+H_{r} F_{r}
$$

where $H_{c}, H_{m}$ and $H_{r}$ represent the hardness of the composite, matrix and reinforcement, respectively, and $F_{m}$ and $F_{r}$ represent the volume fraction of the matrix and reinforcement, respectively.

\subsection{Compression Analysis of Al-Si ${ }_{3} \mathrm{~N}_{4}-\mathrm{GNPs}$ Composites}

Figure 8 represents the compression test results of the developed $\mathrm{Al}_{-} \mathrm{Si}_{3} \mathrm{~N}_{4}-\mathrm{GNPs}$ composites with various content of GNPs. Figure 8a represents the engineering stress/strain curve of the developed $\mathrm{Al}-\mathrm{Si}_{3} \mathrm{~N}_{4}$-GNPs composites. The corresponding compressive yield strength (CYS) and ultimate compression strength (UCS) of the composites are illustrated 
in Figure $8 \mathrm{~b}$. It can be noticed that the compression strength has increased significantly with the addition of $\mathrm{Si}_{3} \mathrm{~N}_{4}$ particles to the Al matrix in (S2) where it has reached its highest UCS value at ( $357 \pm 5 \mathrm{MPa})$ and at $0.2 \%$ offset CYS value of $(103 \pm 4 \mathrm{MPa})$. This behavior of improvement in mechanical properties is a consequence of the effective load transfer $\sigma_{\text {load }}$ which occurs between the ductile $\mathrm{Al}$ matrix and the hard-ceramic phase $\left(\mathrm{S}_{\mathrm{i} 3} \mathrm{~N}_{4}\right)$ reinforcement. The interfacial interaction between the reinforcement phase and the matrix promotes the load transfer and is presented by the following equation [38].

$$
\sigma_{\text {load }}=0.5 V_{f} \sigma_{Y M}
$$

The volume fraction of the ceramic reinforcement in the equation is represented by $V_{f}$ and $\sigma_{Y M}$ denotes the yield stress of the matrix.

Moreover, upon the crack propagation, the resistant to dislocation offered by the reinforcement (secondary phase) significantly increase the strength of the Al-Si $3 \mathrm{~N}_{4}$-GNPs composites, which is in agreement with Orowan mechanism [39]. Additionally, the interaction of the dislocation and secondary phase particles creates a dislocation loop that resists the propagation of crack [36], uniformly dispersed hard reinforcement $\left(\mathrm{Si}_{3} \mathrm{~N}_{4}\right)$ throughout the matrix promotes the nucleation of dislocation loops $[40,41]$. Furthermore, the work of dispersion hardening supports the strength of the material to withstand the maximum applied load [42,43].

The ultimate compressive strength has diminished with the addition of the GNPs to $\mathrm{Al}-\mathrm{Si}_{3} \mathrm{~N}_{4}$-GNPs composites where it reached its terminal value at (312 $\left.\pm 7 \mathrm{MPa}\right)$ and at $0.2 \%$ offset CYS value of (72 $\pm 2 \mathrm{MPa})$ at a uniform failure strain of 0.63 in S5 sample. This drop in the compressive strength can be attributed to the agglomeration of GNPs in the composites due to excessive amount, hence weakens the interface between $\mathrm{Al}$ particles and GNPs leading to strength deterioration [24,29,44]. Furthermore, the grain boundary spaces or pores increases with the increasing content of GNPs because of the pi-pi interaction between different graphene nanoplatelets [45]. The porosity in $\mathrm{Al}-\mathrm{Si}_{3} \mathrm{~N}_{4}-\mathrm{GNPs}$ composites has a negative effect on the sinterability of these composites. The presence of pores due to GNPs agglomerates or overlapping of GNPs leads to crack initiation during the compressive loading and hence adversely affects the compressive strength of the developed composites. Another reason is due to the lubricating nature of graphene which triggers the graphene sheets to slide easily under compression loading, hence, it reduces the friction between hard ceramic particles of $\mathrm{Si}_{3} \mathrm{~N}_{4}$ allowing it to slide during the plastic deformation region under compressive loading which leads to a degradation in the compressive strength [17]. Additionally, the weak Van der Waals force between the graphene sheets enhances the shifting of the sheets under applied loading which in turns decreases the compressive strength [46].

However, even with this drop of strength, the CYS of developed $\mathrm{Al}_{-} \mathrm{Si}_{3} \mathrm{~N}_{4}$-GNPs composites (S3, S4, and S5) is exhibiting improvement of $\sim 87.7 \%, \sim 65.3 \%$ and $\sim 47 \%$ respectively when compared to the pure Al matrix. Moreover, the UCS of developed Al-Si $\mathrm{N}_{4}-\mathrm{GNPS}$ composites (S3, S4, and S5) have also shown an improvement of $\sim 12.4 \%, \sim 8.1 \%$, and $\sim 2 \%$ respectively when compared to the pure $\mathrm{Al}$ matrix. These findings are consistent with the previous studies [24,47]. These improved values of CYS and UCS of (S3, S4, and S5) have exhibited the beneficial role of the inclusion of GNP reinforcement into the Al matrix. 


\section{(a)}

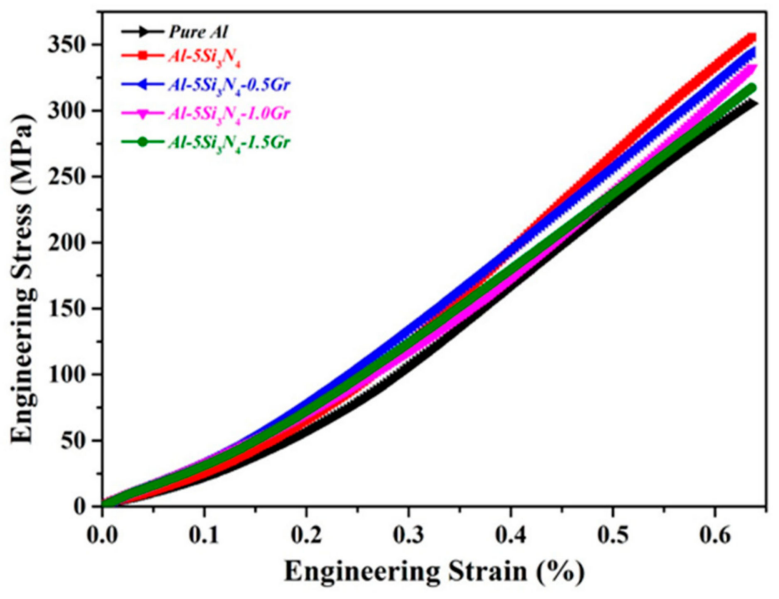

(b)

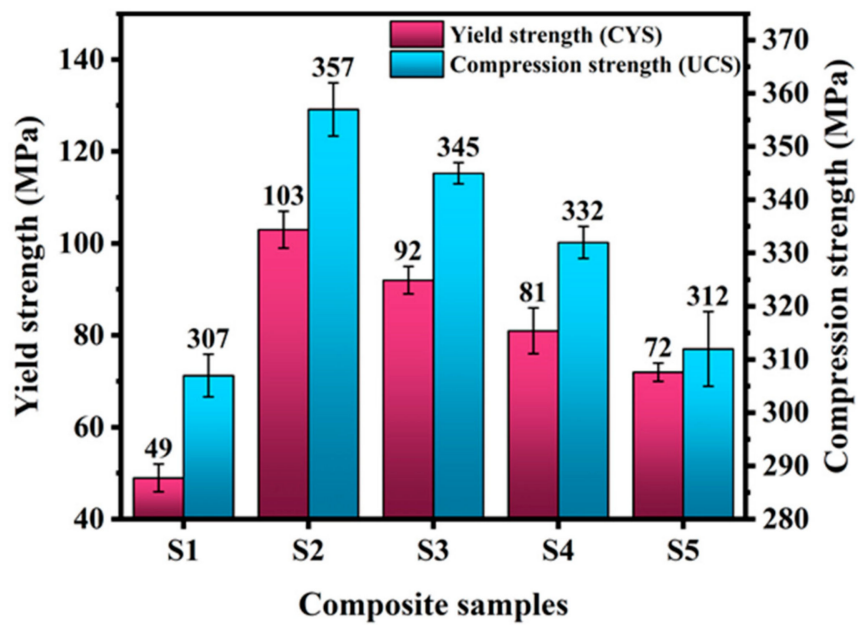

Figure 8. (a) Engineering stress-strain curve under compressive loading (b) Compressive yield strength (CYS) and ultimate compressive strength (UCS) values of $\mathrm{Al}-\mathrm{Si}_{3} \mathrm{~N}_{4}$-GNPs composite samples.

\subsection{Fractography of $\mathrm{Al}_{-} \mathrm{Si}_{3} \mathrm{~N}_{4}$-GNPs Composites}

Figure 9 shows SEM representations of the fractured surfaces of $\mathrm{Al}$ and $\mathrm{Al}_{-} \mathrm{Si}_{3} \mathrm{~N}_{4}{ }^{-}$ GNPs composites under compression loadings. The provided images demonstrate the shear mode fracture that occurred in the composites along with cracks on the surfaces of the samples in the direction of the compressive loading axis at a $45^{\circ}$ angle. As indicated from the images, the compressive deformation of the $\mathrm{Al}$ used as a matrix is different from that of $\mathrm{Al}-\mathrm{Si}_{3} \mathrm{~N}_{4}$-GNPs composites, due to the work hardening effect and the heterogeneous deformation $[14,19]$.
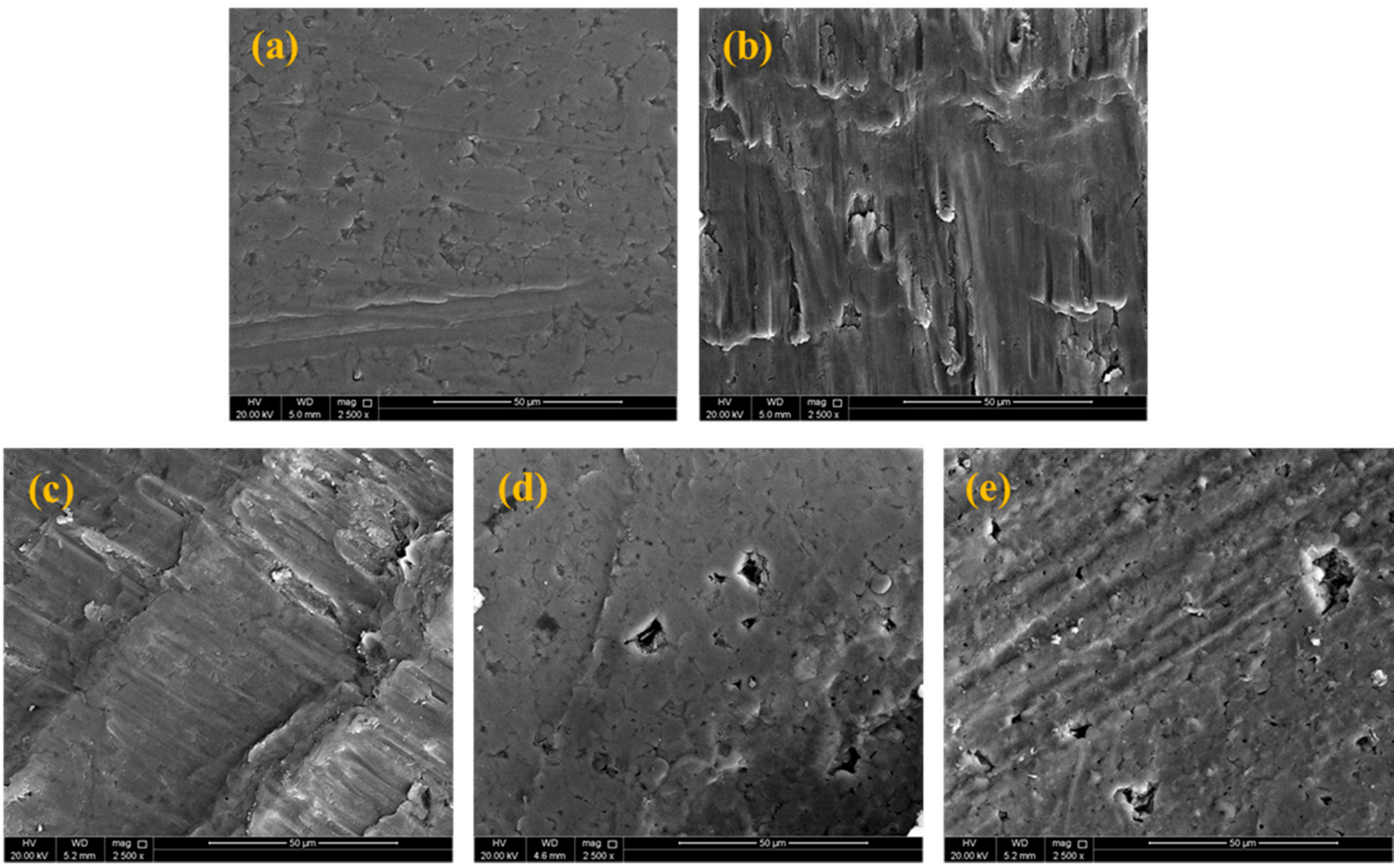

Figure 9. Compression fracture images of (a) Pure Al, (b) $\mathrm{Al}-5 \mathrm{Si}_{3} \mathrm{~N}_{4}$, (c) $\mathrm{Al}-5 \mathrm{Si}_{3} \mathrm{~N}_{4}-0.5 \mathrm{GNPs}$, (d) $\mathrm{Al}-5 \mathrm{Si}_{3} \mathrm{~N}_{4}-1 \mathrm{GNPs}$ and (e) Al-5Si ${ }_{3} \mathrm{~N}_{4}-1.5 \mathrm{GNPs}$ composites. 


\section{Conclusions}

In this study, $\mathrm{Al}_{-} \mathrm{Si}_{3} \mathrm{~N}_{4}$-GNPs composites containing different concentrations of GNPs were successfully synthesized using the microwave-assisted powder metallurgy method. The structural (XRD) and compositional analyses (EDX) confirm the formation of phase pure $\mathrm{Al}-\mathrm{Si}_{3} \mathrm{~N}_{4}$-GNPs composites having an agglomeration effect with increasing concentration of GNPs. The density of the prepared composites decreases with the increasing amount of GNPs, while the porosity follows an opposite trend. The surface roughness of the $\mathrm{Al}-\mathrm{Si}_{3} \mathrm{~N}_{4}$-GNPs composites increases with the exhibit promising hardness as compared to pure Al. Although, the values of CYS and UCS of Al-Si ${ }_{3} \mathrm{~N}_{4}$-GNPs composites decrease with the increasing amount of GNPs but remain higher than the pure Al justifying the motivation of their development. A shear mode of fracture is prevalent in $\mathrm{Al}-\mathrm{Si}_{3} \mathrm{~N}_{4}$-GNPs composites under compressive loading.

Author Contributions: Conceptualization, R.A.S.; Investigation, R.A., A.K. and A.A.; Methodology, R.A.; Resources, M.Y. and A.A.; Software, A.K.; Supervision, R.A.S.; Validation, M.Y.; Writingoriginal draft, R.A.; Writing-review and editing, R.A.S. All authors have read and agreed to the published version of the manuscript.

Funding: The APC will be funded by Qatar National Library, Qatar.

Institutional Review Board Statement: Not applicable.

Informed Consent Statement: Not applicable.

Data Availability Statement: Not applicable.

Acknowledgments: The authors would like to appreciably acknowledge Qatar University's Central Laboratories Unit (QUCLU) for their assistance with the FE-SEM and EDX analysis of the samples.

Conflicts of Interest: The authors declare no conflict of interest.

\section{References}

1. Malaki, M.; Xu, W.; Kasar, A.K.; Menezes, P.L.; Dieringa, H. Advanced Metal Matrix Nanocomposites. Metals 2019, 9, 330. [CrossRef]

2. El-Ghazaly, A.; Anis, G.; Salem, H.G. Effect of graphene addition on the mechanical and tribological behavior of nanostructured AA2124 self-lubricating metal matrix composite. Compos. Part A Appl. Sci. Manuf. 2017, 95, 325-336. [CrossRef]

3. Mohanty, R.M.; Balasubramanian, K.; Seshadri, S.K. Boron carbide-reinforced alumnium 1100 matrix composites: Fabrication and properties. Mater. Sci. Eng. A 2008, 498, 42-52. [CrossRef]

4. Lloyd, D.J. Particle reinforced aluminium and magnesium matrix composites. Int. Mater. Rev. 1994, 39, 1-23. [CrossRef]

5. Lee, J.-M.; Lee, S.-K.; Hong, S.-J.; Kwon, Y.-N. Microstructures and thermal properties of A356/SiCp composites fabricated by liquid pressing method. Mater. Des. 2012, 37, 313-316. [CrossRef]

6. Seyed Pourmand, N.; Asgharzadeh, H. Aluminum Matrix Composites Reinforced with Graphene: A Review on Production, Microstructure, and Properties. Crit. Rev. Solid State Mater. Sci. 2020, 45, 289-337. [CrossRef]

7. Guo, D.; Xie, G.; Luo, J. Mechanical properties of nanoparticles: Basics and applications. J. Phys. D. Appl. Phys. 2013, 47, 13001. [CrossRef]

8. Królczyk, G.; Feldshtein, E.; Dyachkova, L.; Michalski, M.; Baranowski, T.; Chudy, R. On the Microstructure, Strength, Fracture, and Tribological Properties of Iron-Based MMCs with Addition of Mixed Carbide Nanoparticulates. Materials 2020, 13, 2892. [CrossRef]

9. Dadkhah, M.; Saboori, A.; Fino, P. An overview of the recent developments in metal matrix nanocomposites reinforced by graphene. Materials 2019, 12, 2823. [CrossRef]

10. Pang, W.; Fan, X.; Wang, K.; Chao, Y.; Xu, H.; Qin, Z. Al-Based Nano-Sized Composite Energetic Materials and Performance. Nanomaterials 2020, 10, 1039. [CrossRef]

11. Abbasi, S.; Peerzada, M.H.; Nizamuddin, S.; Mubarak, N.M. Chapter 25-Functionalized nanomaterials for the aerospace, vehicle, and sports industries. In Handbook of Functionalized Nanomaterials for Industrial Applications; Mustansar Hussain, C., Ed.; Elsevier: Amsterdam, The Netherlands, 2020; pp. 795-825. ISBN 978-0-12-816787-8.

12. Adalet, Z. Effect of the graphite content on the tribological properties of hybrid $\mathrm{Al} / \mathrm{SiC} / \mathrm{Gr}$ composites processed by powder metallurgy. Ind. Lubr. Tribol. 2015, 67, 262-268. [CrossRef]

13. Penchal Reddy, M.; Shakoor, R.A.; Mohamed, A.M.A.; Gupta, M. Microwave rapid sintering of al-metal matrix composites: A review on the effect of reinforcements, microstructure and mechanical properties. Metals 2016, 6, 143. [CrossRef]

14. Ubaid, F.; Matli, P.R.; Shakoor, R.A.; Parande, G.; Manakari, V.; Mohamed, A.; Mohamed, A.; Gupta, M. Using B 4 C Nanoparticles to Enhance Thermal and Mechanical Response of Aluminum. Materials 2017, 10, 621. [CrossRef] [PubMed]

15. Paknia, A.; Pramanik, A.; Dixit, A.R.; Chattopadhyaya, S. Effect of Size, Content and Shape of Reinforcements on the Behavior of Metal Matrix Composites (MMCs) Under Tension. J. Mater. Eng. Perform. 2016, 25, 4444-4459. [CrossRef] 
16. Rosamah, E.; Hossain, M.S.; Khalil, H.P.S.A.; Nadirah, W.O.W.; Dungani, R.; Amiranajwa, A.S.N.; Suraya, N.L.M.; Fizree, H.M.; Omar, A.K.M. Properties enhancement using oil palm shell nanoparticles of fibers reinforced polyester hybrid composites. Adv. Compos. Mater. 2017, 26, 259-272. [CrossRef]

17. Ahmad, S.I.; Hamoudi, H.; Abdala, A.; Ghouri, Z.K.; Youssef, K.M. Graphene-Reinforced Bulk Metal Matrix Composites: Synthesis, Microstructure, and Properties. Rev. Adv. Mater. Sci. 2020, 59, 67-114. [CrossRef]

18. Rahimian, M.; Ehsani, N.; Parvin, N.; Baharvandi, H.R. The effect of particle size, sintering temperature and sintering time on the properties of $\mathrm{Al}-\mathrm{Al}_{2} \mathrm{O}_{3}$ composites, made by powder metallurgy. J. Mater. Process. Technol. 2009, 209, 5387-5393. [CrossRef]

19. Saboori, A.; Dadkhah, M.; Fino, P.; Pavese, M. An overview of metal matrix nanocomposites reinforced with graphene nanoplatelets; mechanical, electrical and thermophysical properties. Metals 2018, 8, 423. [CrossRef]

20. Sharma, P.; Sharma, S.; Khanduja, D. Production and some properties of Si $3 \mathrm{~N} 4$ reinforced aluminium alloy composites. Integr. Med. Res. 2018, 3, 352-359. [CrossRef]

21. Chung, Y.-K.; Koo, J.-H.; Kim, S.-A.; Chi, E.-O.; Cho, J.-Y.; Sohn, W.-B.; Kim, M.-Y.; Park, C. Growth mechanism of Si ${ }_{3} N_{4}$ nanowires from amorphous Si3N4 powders synthesized by low-temperature vapor-phase reaction. Cryst. Eng. Comm. 2016, 18, 3247-3255. [CrossRef]

22. Jeon, C.-H.; Jeong, Y.-H.; Seo, J.-J.; Tien, H.N.; Hong, S.-T.; Yum, Y.-J.; Hur, S.-H.; Lee, K.-J. Material properties of graphene/aluminum metal matrix composites fabricated by friction stir processing. Int. J. Precis. Eng. Manuf. 2014, 15, 1235-1239. [CrossRef]

23. Rafiee, M.A.; Rafiee, J.; Wang, Z.; Song, H.; Yu, Z.Z.; Koratkar, N. Enhanced mechanical properties of nanocomposites at low graphene content. ACS Nano 2009, 3, 3884-3890. [CrossRef]

24. Şenel, M.C.; Gürbüz, M.; Koç, E. Fabrication and characterization of aluminum hybrid composites reinforced with silicon nitride/graphene nanoplatelet binary particles. J. Compos. Mater. 2019, 53, 4043-4054. [CrossRef]

25. Gürbüz, M.; Can Şenel, M.; Koç, E. The effect of sintering time, temperature, and graphene addition on the hardness and microstructure of aluminum composites. J. Compos. Mater. 2018, 52, 553-563. [CrossRef]

26. Alam, S.N.; Kumar, L. Mechanical properties of aluminium based metal matrix composites reinforced with graphite nanoplatelets. Mater. Sci. Eng. A 2016, 667, 16-32. [CrossRef]

27. Khan, A.; Abdelrazeq, M.W.; Mattli, M.R.; Yusuf, M.M.; Alashraf, A.; Matli, P.R.; Shakoor, R.A. Structural and mechanical properties of Al-SiC- $\mathrm{ZrO}_{2}$ nanocomposites fabricated by microwave sintering technique. Crystals 2020, 10, 904. [CrossRef]

28. Dou, Y.C.; Qin, X.Y.; Li, D.; Li, Y.Y.; Xin, H.X.; Zhang, J.; Liu, Y.F.; Song, C.J.; Wang, L. Enhanced thermoelectric performance of BiSbTe-based composites incorporated with amorphous Si3N4 nanoparticles. RSC Adv. 2015, 5, 34251-34256. [CrossRef]

29. Tian, W.-M.; Li, S.-M.; Wang, B.; Chen, X.; Liu, J.-H.; Yu, M. Graphene-reinforced aluminum matrix composites prepared by spark plasma sintering. Int. J. Miner. Metall. Mater. 2016, 23, 723-729. [CrossRef]

30. Das, D.K.; Mishra, P.C.; Singh, S.; Thakur, R.K. Properties of ceramic-reinforced aluminium matrix composites-A review. Int. J. Mech. Mater. Eng. 2014, 9, 1-16. [CrossRef]

31. Gürbüz, M.; Mutuk, T. Effect of process parameters on hardness and microstructure of graphene reinforced titanium composites. J. Compos. Mater. 2018, 52, 543-551. [CrossRef]

32. ADe Araujo, E.R.; De Souza, M.M.S.; Filho, F.A.; Gonzalez, C.H.; Filho, O. Preparation of Metal Matrix Aluminum Alloys Composites Reinforced by Silicon Nitride and Aluminum Nitride Through Powder Metallurgy Techniques. Mater. Sci. Forum. 2012, 728, 259-262. [CrossRef]

33. Wang, Y.; Shi, J.; Lu, S.; Xiao, W. Investigation of porosity and mechanical properties of graphene nanoplatelets-reinforced AlSi10 Mg by selective laser melting. J. Micro Nano Manuf. 2018, 6, 1-7. [CrossRef]

34. Khan, A.; Matli, P.R.; Nawaz, M.; Mattli, M.R.; Parande, G.; Manakari, V.; Shakoor, A.; Aljaber, A.S.; Gupta, M. Microstructure and mechanical behavior of hot extruded aluminum/tin-bismuth composites produced by powder metallurgy. Appl. Sci. 2020, 10, 2812. [CrossRef]

35. Ashraf, P.M.; Thomas, S.N.; Edwin, L. Development of graphene-nanometre-sized cerium oxide-incorporated aluminium and its electrochemical evaluation. Appl. Nanosci. 2016, 6, 149-158. [CrossRef]

36. Matli, P.R.; Ubaid, F.; Shakoor, R.A.; Parande, G.; Manakari, V.; Yusuf, M.; Amer Mohamed, A.M.; Gupta, M. Improved properties of $\mathrm{Al}-\mathrm{Si}_{3} \mathrm{~N}_{4}$ nanocomposites fabricated through a microwave sintering and hot extrusion process. RSC Adv. 2017, 7, 34401-34410. [CrossRef]

37. Bisht, A.; Srivastava, M.; Kumar, R.M.; Lahiri, I.; Lahiri, D. Strengthening mechanism in graphene nanoplatelets reinforced aluminum composite fabricated through spark plasma sintering. Mater. Sci. Eng. A 2017, 695, 20-28. [CrossRef]

38. Luster, J.W.; Thumann, M.; Baumann, R. Mechanical properties of aluminium alloy $6061-\mathrm{Al}_{2} \mathrm{O}_{3}$ composites. Mater. Sci. Technol. 1993, 9, 853-862. [CrossRef]

39. Zhang, Z.; Chen, D.L. Consideration of Orowan strengthening effect in particulate-reinforced metal matrix nanocomposites: A model for predicting their yield strength. Scr. Mater. 2006, 54, 1321-1326. [CrossRef]

40. Zhou, X.B.; Qiu, F.G.; Reddy, M.P.; Han, Y.H.; Lee, J.; Huang, Q. Comparative study of conventional and microwave sintered mullite fibres: Structural study. Adv. Appl. Ceram. 2015, 114, 139-143. [CrossRef]

41. Zhao, L.; Lu, H.; Gao, Z. Microstructure and Mechanical Properties of Al/Graphene Composite Produced by High-Pressure Torsion. Adv. Eng. Mater. 2015, 17, 976-981. [CrossRef] 
42. Alizadeh, M. Strengthening mechanisms in particulate Al/B 4C composites produced by repeated roll bonding process. J. Alloys Compd. J. Alloys Compd. 2011, 509, 2243-2247. [CrossRef]

43. Matli, P.R.; Fareeha, U.; Shakoor, R.A.; Mohamed, A.M.A. A comparative study of structural and mechanical properties of Al-Cu composites prepared by vacuum and microwave sintering techniques. J. Mater. Res. Technol. 2018, 7, 165-172. [CrossRef]

44. Pérez-Bustamante, R.; Bolaños-Morales, D.; Bonilla-Martínez, J.; Estrada-Guel, I.; Martínez-Sánchez, R. Microstructural and hardness behavior of graphene-nanoplatelets/aluminum composites synthesized by mechanical alloying. J. Alloys Compd. 2015, 615, S578-S582. [CrossRef]

45. Uzunsoy, D. Processing and characterization of graphene nano-platelet (GNP) rein-forced aluminum matrix composites. Mater. Test. 2016. [CrossRef]

46. Güler, Ö.; Ba, N. A short review on mechanical properties of graphene reinforced metal matrix composites. J. Mater. Res. Technol. 2020, 9, 6808-6833. [CrossRef]

47. Rashad, M.; Pan, F.; Tang, A.; Asif, M. Effect of Graphene Nanoplatelets addition on mechanical properties of pure aluminum using a semi-powder method. Prog. Nat. Sci. Mater. Int. 2014, 24, 101-108. [CrossRef] 